\title{
LAUKU PAŠVALDĪBAS KĀ SABIEDRĪBAS ATJAUNOŠANAS AG̣ENTI
}

\author{
Ženija Krūzmētra', Dina Bite' ${ }^{1}$, Linda Lotina ${ }^{2}$ \\ ${ }^{1}$ Latvijas Lauksaimniecības universitāte, e-pasts: zenija.kruzmetra@llu.lv, dina.bite@llu.lv \\ 2 Vidzemes Augstskola, e-pasts: linda.lotina@va.Iv
}

\begin{abstract}
Anotācija. Lauku pašvaldības ir viens no galvenajiem ağentiem vietējās sabiedrības atjaunošanai. Lauku depopulācijas procesi aktualizē iedzīvotāju līdzdalību dažādās aktivitātēs, tai skaitā kultūrvides revitalizācijā, kas veicinātu vietu sociālekonomisko attīstību un teritoriju ilgtspēju. Lai šis process būtu produktīvs un mērḳorientēts, tas ir profesionāli jāvada, tāpēc aktuāls ir labas pārvaldības jautājums. Kā viens no att̄̄stības virzieniem iezīmējas vietējo iedzīvotāju nozīmes stiprināšana, kuri vēl ir neizmantots resurss radošai inovatīvai rīcībai. Pētījumā izmantotas kvalitatīvās pētniecības metodes - dokumentu analīze, dą̧̣eji strukturētas intervijas; dati iegūti, veicot izpēti Mazsalacas, Krāslavas, Engures, Kandavas novadā un Sabiles pilsētā 2015. gadā. Pētījums fokusējas uz lauku pašvaldību darbu ar vietējo kopienu kultūrvides attīstībā. Pētījuma rezultāti iezīmē iespējamās rīcības situācijas uzlabošanai gan izpētes teritorijās, gan citās lauku pašvaldībās ar līdzīgām problēmām. Pētỉjums tiek veikts Valsts Pētījumu Programmas EKOSOC 5.2. projektu ietvaros (projekts 5.2.4 un 5.2.8).
\end{abstract}

Atslēgas vārdi: lauku pašvaldības, laba pārvaldība, sabiedrības atjaunošana, kultūrvide.

\section{Ievads}

Latvijā tāpat kā daudzās Eiropas valstīs lauki piedzīvo dažādus transformācijas procesus - demogrāfiskos, ekonomiskos un sociālos, kā rezultātā lauku teritoriju pašvaldības un iedzīvotāji spiesti meklēt risinājumus gan individuālai, gan kopienas līmeņa izdzīvošanai. Tā, piemēram, Mazsalacā, līdzīgi kā daudzos Latvijas novados, iedzīvotāju skaits samazinās gan kopumā (no 5123 iedzīvotājiem 2000. gadā, līdz 3314 - 2014. gadā), gan katrā atsevišķā apdzīvotā vietā. Lauku depopulācijas procesi aktualizē uzdevumu aktivizēt vietējo sabiedrību iesaistīties kultūrvides revitalizācijā, kas veicinātu apdzīvotu vietu sociālo un ekonomisko attīstību, teritoriju ilgtspēju un sabiedrības atjaunošanu (Lawton et al. 2014; Williams 2008; Steiner 2000). Lai šis process būtu produktīvs un mērḳorientēts, tas ir profesionāli jāvada, tāpēc aktuāls ir labas pārvaldības jautājums (Wilke 2007) un dažāda līmeņa stratēg̣iju izstrāde (Cultural Environment... 2014). 


\section{Materiāls un metodes}

Pētījumā izmantota kvalitatīvā pētījuma pieeja - dokumentu analīze (pašvaldību attīstības dokumenti), izpētes teritoriju apsekojums, novērojumi un daḷēji strukturētas intervijas ar pašvaldību darbiniekiem, muzeju un tūrisma informācijas centru darbiniekiem, mazajiem uzņēmējiem, zemnieku saimniecību īpašniekiem un dažādu pakalpojumu sniedzējiem, kuri savā darbībā izmanto dabas un kultūrvēsturiskā mantojuma resursus. Pētījums veikts Mazsalacas, Krāslavas, Engures, Kandavas novadā un Sabiles pilsētā 2015. gadā.

\section{Rezultāti, to interpretācija}

Iepazīstoties ar novadu attīstības dokumentiem (attīstības plāniem, stratēgijiām, ilgtspējīgas attīstības stratēgijām) apdzīvojuma attīstības kontekstā, lauku novadi savos attīstības dokumentos ir pievērsuši uzmanību apdzīvojuma attīstības nozīmei, akcentējot gan dominējošo demogrāfisko tendenci - depopulāciju, gan nepieciešamību palielināt iedzīvotāju skaitu, gan attīstît apdzīvotās vietas. Tāpat tajos tiek uzsvērtas dažādas novadu dabas vides un kultūrvēsturiskās vērtības, pausts uzskats, ka novads ir pievilcīga vieta dzīvošanai ǵimenēm ar bērniem, nereti pierobežu novadi postulē sevi kā pieņemamu dz̄ives vidi tieši sociāli mazaizsargātajām iedzīvotāju grupām.

Īpaši jāuzsver Sabiles pašvaldības pārvaldes vadītāja stāstījums par Talsu novada mērḳtiecīgu darbību iedzīvotāju piesaistē, veidojot pievilcīgu dzīves vidi ne tikai vietējiem iedzīvotājiem, bet arī iebraucējiem no Rīgas un citām vietām, kuri iegādājas brīvdienu mājas, lai perspektīvā pārceltos uz pastāvīgu dzīvi Sabilē. Šì laika aktualitāte ir jauna bērnudārza celtniecība, lai veidotu pievilcīgu vidi ğimenēm ar bērniem. Tik pārdomāta pieeja iedzīvotāju piesaistei no pašvaldības puses netika pausta citos apmeklētajos novados. Zināmā mērā var runāt par pašvaldību specializēšanos noteiktu sociālu kategoriju piesaistē (piemēram, pensionāri, ğimenes ar bērniem). Tajā pašā laikā jāteic, ka, lai gan visas pētījumā iesaistītās pašvaldības labprāt redzētu iedzīvotāju skaita pieaugumu, ne vienmēr pašvaldību attīstības dokumentos ir skaidri definēti iedzīvotāju piesaistes instrumenti.

Interviju rezultāti atklāj, ka būtisks vietējās sabiedrības aktivizēšanas un sabiedrības atjaunošanas priekšnosacījums ir sadarbība starp dažādiem aǵentiem, uzticēšanās un vienotu mērḳu nepieciešamība. Tā veicināšanai vispirms būtu jāstiprina esošo iedzīvotāju nozīme novadā, ideālā variantā svarīgi būtu aktualizēt ikviena vietējā iedzīvotāja nozīmi novadā. Vietējo iedzīvotāju nozīmes stiprināšanai novados būtisks pašvaldības instruments ir komunikācija ar vietējo sabiedrību. Pozitīvs piemērs ir Sēli, kur pagasta pārvaldes speciālisti izprot komunikācijas mehānismu ar vietējiem iedzīvotājiem, apzinās, ka lauku iedzīvotāji ir jāuzrunā individuāli: „visvairāk ir darbs pie cilvēku uzrunāšanas, tad aiziet informācija mute mutē”, kā rezultātā Sēlos organizētie pasākumi tiek labi apmeklēti. Iedzīvotāji jūt, ka viņi patiešām tiek gaidīti, jūtas piederīgi pie Sēḷu pagasta/kultūrtelpas. Savukārt novada domes sabiedrisko attiecību speciāliste uzsver iedzīvotāju zemo aktivitāti, tomēr pasīvo iedzīvotāju daḷu īpaši neuzrunā, uzskatot, ka „informācija ir izlasāma un tas ir priekš visiem”. Publiskās apspriešanas ir 
mazapmeklētas ,pagastos ir švaki ar atsaucību, atnāk 7-8 deputāti un 3-4 iedzīvotāji’”, „....tā ir sāpe priekšsēdētājam”. Speciāliste atkārtoti pauž nevēlēšanos veikt kādas papildus aktivitātes: „Vai tad mums jāiet likt zìmìtes pie katrām durvìm?” Arī no vietējo zemnieku puses izskan vēlme pēc tiešas individuālas komunikācijas ar novada priekšsēdētāju, speciālistiem. Šis piemērs un interviju rezultāti kopumā rāda, ka šeit slēpjas vēl neizmantots potenciāls un ka komunikācijas pilnveidošana ir vitāli svarīgs priekšnoteikums kopienas aktivizēšanai, lai to iesaistītu dažādos attīstības procesos un pasākumos, lai veidotu uzticības kapacitāti. Jāuzsver, ka mazās kopienās darbojas citi komunikācijas mehānismi, kur atsvešinātība un formāla komunikācija nav efektīva.

Pašvaldībām jāmeklē jauni kopienas iesaistes instrumenti, kopiena jāizglīto ne tikai ar masu, sociālo mediju vai formālu semināru starpniecību, bet personalizētām neformālām sarunām, kas ir îpaši efektīva komunikācijas forma nelielās lauku kopienās. Lai iedzīvotāji uzticētos un iesaistītos kapacitātes veidošanā, pašvaldībām būtu mērķtiecīgāk jāpopularizē novadu labās prakses piemēri vietējā kopienā un arī plašāk, lai tie parādītu ar pašiniciatīvu un pašaktivitāti sasniegtos rezultātus, kas ir viens no veiksmīgas endogenās attīstības priekšnosacījumiem. Akcentējot pašvaldības speciālistu nozīmi vietējās sabiedrības aktivizēšanā, svarīgas ir arī viṇu personīgās īpašības, vēlme un interese darboties. Tā Kandavas novada vadītāja maiņa veicinājusi kultūrvides attīstību ,tagadējā valdība ir daudz ieinteresētāka, kā iepriekšèjā". Atsevišķos gadījumos labas pārvaldības uzdevumi izvirza arī nepieciešamību mainīt pašvaldību speciālistu attieksmi, jo ne visi atzīst, ka iedzīvotājs ir pilntiesīgs partneris, kura viedoklis jārespektē, veidojot līdzvērtīgu dialogu un sadarbību. Iedzīvotāju iesaiste kultūrvides attīstības procesos pašlaik vērtējams kā nozīmīgākais resurss to lauku teritoriju attīstībā, kur apsīkusi gan ekonomiskā, gan sociālā aktivitāte. Pie tam kultūrvides norisēs var iesaistīties jebkurš novada iedzīvotājs, kaut vai, piemēram, savas tuvākās vai tālākās apkārtnes sakopšanā.

\section{Secinājumi}

İpaši svarīga lauku pašvaldību kā sabiedrības atjaunošanas aǵentu loma ir lauku teritorijās ar zemu ekonomisko un sociālo aktivitāti. Pētījuma rezultāti rāda, ka pašvaldības sabiedrības atjaunošanai piešķir atšķirīgu nozīmi un īsteno atšķirīgu stratēgiju. Perspektīvs potenciāls ir komunikācijas uzlabošana ar vietējiem iedzīvotājiem, lokālas attīstības stratēgijas izstrāde, labās prakses popularizēšana, attieksmes maiṇa sadarbībā ar vietējiem iedzīvotājiem.

\section{Pateicība}

Publikācija tapusi ar Valsts pētījumu programmas EKOSOC projektu 5.2.4 un 5.2.8. ietvaros. Pateicamies prof. Z. Krišjānei, prof. J. Krūmiņam, prof. A. Līviņai par atbalstu. 
Atsauces

Cultural Environment Strategy 2014-2020 (2014) Ministry of Education and Culture, Ministry of the Environment, Helsinki, p. 29. Sk. 20.12.2015., pieejams: https://helda.helsinki.fi/bitstream/handle/10138/135508/Cultural\%20Environment\%20Strategy _2014.pdf?sequence=1

Lawton, K., Cooke, G., Pearce, N. (2014). The Conditions of Britain. Strategies for Social Renewal. Institute for Public Policy Research, London

Steiner, R. (2000). Towards Social Renewal, Rethinking the Basis of Society. Retrieved: http://www.threefolding.org/archiv/800.html, (28.12.2015)

Williams, N. (2008). The Source of Social Renewal. Retrieved: http://www.thinkoutword.org/pdfs/nathaniel_williams_essay.pdf, (28.12.2015)

Willke H. (2007) Smart Governance. Governing the Global Knowledge Society. The University Chicago Press.

\section{Summary}

Smart governance is challenge for rural municipalities in Latvia due to depopulation and shrinking processes in rural areas. Rural municipalities, as agents of society renewal, are tasked with promoting citizens' participation in different activities of local development, including revitalization of the cultural environment, in order to promote socio-economic development, community renewal, population development and spatial sustainability of the area. To make this process more productive and purposeful, it must be managed competently; thus, the issue of good governance is especially important. This study uses qualitative research methods - document analysis and semi-structured interviews. Data was obtained by studying the districts of Mazsalaca, Kraslava, Engure, and Kandava, as well as the town of Sabile, starting in 2015. Research results suggest that an essential instrument used by municipalities for strengthening of the role of local residents in districts is communication with the local community, the building of the capacity for trust and participation, and popularization of examples of good practices in local community and on a larger scale, demonstrating what results can be achieved by the self-initiative and self-activity that are one of preconditions for successful endogenous development. The research was conducted as a part of the State Research Program EKOSOC 5.2. (projects 5.2.4 and 5.2.8). 